\section{Origin of Soil Mounds Associated with Clumps of Ribes velutinum}

\section{DALE V. SAUNDERS, JAMES A. YOUNG, AND RAYMOND A. EVANS}

Highlight: The mounds of soil associated with multi-stem clumps of Ribes velutinum Greene are apparently the result of rodent activity and are not remnant erosion surfaces. The development of the mounds is a dynamic response to stand renewal by burning. Rodents apparently are attracted by the increase in annuals, especially downy brome, which occurs after fire. The protection of the spiney clumps of resprouting Ribes provides a safe place for the rodents to build their dens.

Range managers must continually make decisions on the condition and trend of rangelands. The soil mounds associated with multiple-stem shrubs have been employed to judge gross trend changes on the basis that the height of the mound reflects the amount of soil erosion that has occurred on the site. Ellison (1954), investigating the subalpine vegetation of the Wasatch Plateau, described Ribes growing on mounds as the only vegetation on high-elevation steep slopes. He suggested that in this situation the mounds represented the original soil surface because the texture, structure, and organic matter content of the surface soil of the mounds reflected a more mesic condition than was currently found between the mounds. Our purpose was to investigate the development of soil mounds associated with clumps of Ribes.

\section{Methods}

We excavated a series of Ribes mounds on Granite Mountain, located $50 \mathrm{~km}$ north of Reno, Nevada. The mounds were located in a series of plant communities at an elevation from 1650 to $1800 \mathrm{~m}$. The area was burned in a wildfire in 1950. The vegetation is now dominated by green rabbitbrush (Chrysothamnus viscidiflorus [Hook.] Nutt.). There is considerable re-invasion of big sagebrush (Artemisia tridentata Nutt.). The herbaceous vegetation on south-facing slopes is dominated by downy brome (Bromus tectorum L.) and redstem filaree

The authors are, respectively, undergraduate research assistant, Renewable Natural Resources Center, College of Agriculture, and range scientists, Agricultural Research Service, U. S. Department of Agriculture, University of Nevada at Reno.

The study represents cooperative investigations of the Agr. Res. Serv., U. S. Dep. Agr., and the Agricultural Experiment Station, University of Nevada, Reno. (University of Nevada Journal Series No. 204.)
(Erodium cicutarium (L.) L'Her.). On the north slopes, succession in the herbaceous vegetation has largely passed from downy brome to Sandberg bluegrass (Poa sandbergii Vasey).

The mounds are associated with Ribes velutinum Greene clumps. The Ribes clumps are largely, but not entirely, located on north-facing slopes. Not every clump of Ribes is growing on a mound. The root sprouting shrub, desert peach (Prunus andersonii Gray), forms dense clumps on both north and south slopes but is not associated with mounds.

The soils in the study area are largely mollic haplargrids derived from decomposing granite. The surface soil has a sandy-loam texture and at about $3 \mathrm{dm}$ in depth grades into a well developed clayloam horizon. Underlying the developed activity. horizon there may be fractured granite or relatively deep beds of coarse decomposing granite.

At Granite Mountain we excavated 10 Ribes clumps; eight clumps with mounds and two clumps without mounds. Trenches were dug across the clumps to a depth of $1.5 \mathrm{~m}$. The occurrence of whorls of growth on Ribes stems, changes of soil texture and structure, evidence of rodent activity, and charcoal and organic matter accumulations were recorded in stratigraphic sequence. Depth control was maintained with the aid of a level and rod.

Soil samples were obtained from the mounds and from the soil surface between the mounds. These samples were analyzed for texture, $\mathrm{pH}$, organic matter, nitrate-nitrogen, phosphorus, potassium, calcium, magnesium, sulfur, and cation exchange capacity.

In addition to studies at Granite Mountain, 10 Ribes clumps were investigaged at each of two more recent wildfire areas. Red Rock Summit, $40 \mathrm{~km}$ north of Reno, was burned in 1968; Silver Knoll, $20 \mathrm{~km}$ north of Reno, was burned in 1970. The soils and physiography of both of these sites were very similar to Granite Mountain. Plant cover at Red Rock Summit was dominated by downy brome. The Silver Knolls burn had a very sparce plant cover composed of forbs with the beginning of a population buildup of downy brome.

$\Lambda t$ all locations, the density of shrubs was determined on 10 plots $10 \mathrm{~m}$ by 10 $\mathrm{m}$ in dimension. The herbaceous vegetation was sampled using the step-point method of Evans and Love (1957).

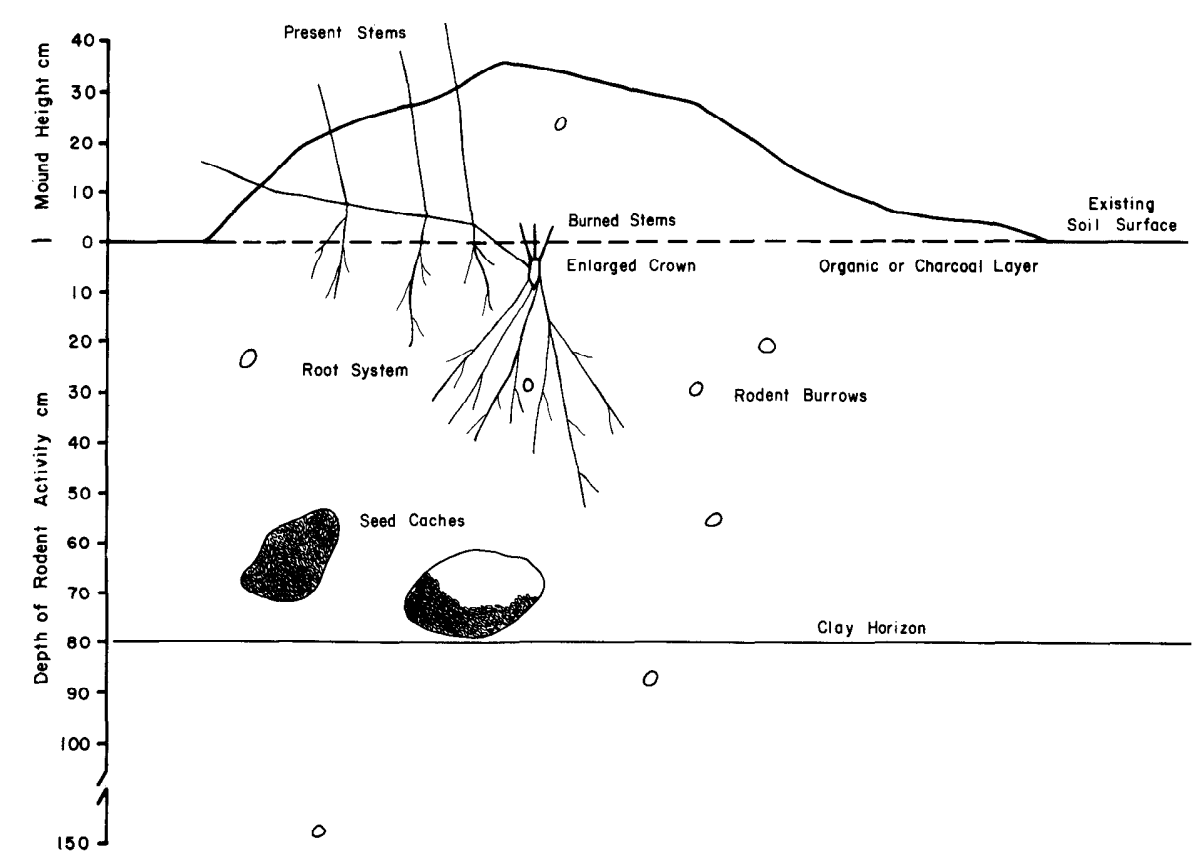

Fig. 1. Cross-section view of typical Ribes mound showing root system and evidence of rodent 


\section{Results}

In all of the mounds excavated at Granite Peak, there was abundant evidence of rodent activity. Tunnels 10 to $30 \mathrm{~cm}$ in diameter extended to $1.5 \mathrm{~m}$ below the soil surface. Seed caches were found in hollows 3 to $4 \mathrm{dm}$ in diameter. These caches contained from 5 to 10 liters of caryopses of downy brome. The caryopses appeared to have been stored for a considerable period for the lemmas and paleac had separated from the remainder of the caryopses and the caryopses would not germinate.

When the vegetation of this community is dominated by annuals, there is a grcat deal of collection and caching of downy brome caryopses by rodents of the family Heteromyidae, especially Dipodomys sp. and Perognathus sp. (LaTourrette et al., 1971). At the current stage of succession of the Granite Peak vegetation, the collectors of downy brome caryopses appear to be gone; and the extensive dens in the Ribes mounds are inhabited by a variety of rodents, reptiles, and insects.

All of the characteristics noted were not evident in every mound, but enough of the features were always present to provide a stratigraphic sequence (Fig. 1).

Besides the universal occurrence of rodent tunnels in the mounds, burned Ribes stems were located well below the surface of the mounds (Fig. 1). Around the burned stems there were whorls of stems which had extended up through the mound to provide the acrial portion of the shrub. The stems extended laterally from the whorl and had roots at their nodes. Apparently, aerial stems were buried but continued to grow to regain the surface. The stems and roots hold the mound in place. Unfortunately, it was impossible to determine annual growth rings in these stems.

At about the same level as the whorl of growth, an organic or charcoal horizon could be traced through the mound (Fig. 1). Viewed in cross section, this horizon appeared to be a continuation of the soil surface on either side of the mound. The organic matter consisted of decomposed downy brome caryopses and herbage. The occasional charcoal horizons which replaced the organic layer appeared to be the remains of woody material.

In two clumps of Ribes without mounds which were excavated at Granite Peak, no evidence of rodent activity was found. The soil profile under the mounds appeared to be a continuation of that found on either side of the clump. No evidence of burned stems was found in these clumps, which apparently were established after the fire.

At Silver Knolls one year after the vegetation was consumed in an intense wildfire, the herbaceous vegetation was dominated by forbs (Table 1). The Ribes crowns were completely consumed by the fire, but shrubs were sprouting in whorls from the burned stems. There was no evidence of mounds or of rodent activity.

Three years after burning at the Red Rock Summit site, the plant community was dominated by downy brome (Table 1). The Ribes clumps had resprouted with stem heights of 2 to $3 \mathrm{dm}$. There was considerable rodent activity associated with these clumps and mounds appeared to be under construction.

Table 1. Frequency $(\%)$ and cover $(\%)$ of herbaceous vegetation and shrub density (per 100 sq. m) at three locations.

\begin{tabular}{lccc}
\hline \hline $\begin{array}{l}\text { Measurement } \\
\text { and species }\end{array}$ & $\begin{array}{c}\text { Silver } \\
\text { Knolls }\end{array}$ & $\begin{array}{c}\text { Red Rock } \\
\text { Summit }\end{array}$ & $\begin{array}{c}\text { Granite } \\
\text { Peak }\end{array}$ \\
\hline $\begin{array}{l}\text { Frequency } \\
\text { Bromus tectorum }\end{array}$ & & & \\
$\quad$ Sisymbrium altissimum & 25 & 64 & 22 \\
$\quad$ Erodium cicutarium & & & \\
$\quad$ Descurainia pinnata & 2 & 4 & 11 \\
Mentzelia albicaulis & 52 & & \\
$\quad$ Lomatium Canbyi & 3 & 16 & \\
$\quad$ Leptodactylon pungens & 3 & 7 \\
Balsomorhiza sagittata & 1 & & \\
$\quad$ Poa Sandbergii & 2 & 8 & 43 \\
$\quad$ Stipa occidentalis & 1 & 2 & 3 \\
$\quad$ Stipa thurberiana & 6.0 & 14 & 7.7 \\
Cover & & & \\
Density & & 6 & 7 \\
$\quad$ Chrysothamnus viscidiflorus & & 2 & 5 \\
$\quad$ Artemisia tridentata & 2 & 1 & 2 \\
$\quad$ Ribes velutinum & 1 & 1 & 1 \\
Prunus Andersonii & 2 & & 1 \\
$\quad$ Tetradymia canescens & & & \\
\hline
\end{tabular}

Table 2. Comparison of surface $15 \mathrm{~cm}$ of soil between and on Ribes mounds.

\begin{tabular}{lcc}
\hline $\begin{array}{c}\text { Soil } \\
\text { characteristics }\end{array}$ & $\begin{array}{c}\text { Between } \\
\text { mounds }\end{array}$ & $\begin{array}{c}\text { On } \\
\text { mounds }\end{array}$ \\
\hline Texture (\%) & & \\
>2 mm & 19.4 & 11.5 \\
$<2 \mathrm{~mm}$ & 62.6 & 70.5 \\
Silt & 15.0 & 14.5 \\
Clay & 3.0 & 3.5 \\
Cation exchange capacity & 7 & 7 \\
$\quad$ (meq/100 g) & & \\
Organic matter $(\%)$ & 2.4 & 2.6 \\
Available nutrients & & \\
NO (ppm N) & 2 & 5 \\
P (ppm) & 105 & 290 \\
Ca (meq/100 g) & 3.6 & -0.6 \\
Mg (meq/100 g) & 4.4 & 1.0 \\
S (ppm) & 8 & 12 \\
\hline
\end{tabular}

\section{Significance of Ribes Mounds to Management}

In this situation the mounds associated with clumps of Ribes appear to be a product of rodent activity and cannot be used to determine rates of soil movement in long-term erosion. In other environments, the mounds may be remnant surfaces left by erosion, but they should always be checked for rodent activity and signs of buried surface horizons.

The mound building may have a long term influence on site quality. The soil on the mounds has been influenced by rodent activity (Table 2). Available nutrients, especially phosphorous and potassium, were higher in the soil of the mounds compared to adjacent soil. Organic matter, soil texture, and cation exchange capacity were not affected by the mound building process. Leaf fall from the shrubs and protection from grazing of the associated herbaceous vegetation by the dense mass of spines of the Ribes clump may account for these differences.

The Ribes clumps severely limit forage and browse production and utilization on these sites. The use of fire or herbicides to control this species must take into account the protection the mounds provide for the sprouting Ribes crowns.

\section{Literature Cited}

Ellison, I. 1954. Subalpine vegetation of the Wasatch Plateau, Utah, Ecol. Monogr. 24:89-184.

Evans, R. A., and R. M. Love, 1957. The step-point method of sampling - A practical tool in range research. J. Range Manage. $10: 208-212$.

LaTourrette, J. E., J. A. Young, and R. A. Evans. 1971. Seed dispersal in relation to rodent activities in seral big sagebrush communities. J. Range Manage. 24:118-120. 